\title{
MENINGKATKAN HASIL BELAJAR SISWA DENGAN MODELLING THE WAY PADA MATA PELAJARAN IPA DI KELAS V SD MUHAMMADIYAH CENDANA ASRI
}

\author{
Erlinda Simanungkalit
}

Surel: erlinda.s@yahoo.com

\begin{abstract}
ABSTRAK
Penelitian ini bertujuan untuk meningkatkan hasil belajar siswa pada materi pokok alat peredaran darah manusia dengan menggunakan model pembelajaran Modelling The Way. Subyek penilitian ini adalah siswa kelas V SD Muhammadiyah Cendana Asri Kec. Batang kuis yang berjumlah 32 siswa. Dari hasil tes yang diberikan kepada 32 orang siswa dari siklus I hingga siklus II, diperoleh hasil dengan nilai rata-rata hasil belajar dengan menggunakan model prmbelajaran Modelling The Way lebih tinggi yakni sebesar 81,8, dengan presentase klasikal sebesar 90,62\%, sedangkan nilai rata-rata sebelum menggunakan model pembelajaran Modelling The Way lebih rendah yakni 52,5 dengan presentase klasikal 3,25\%.
\end{abstract}

Kata Kunci: Hasil Belajar, Model Pembelajaran, Modelling The Way

\section{PENDAHULUAN}

Pada masa yang akan datang penguasaan dunia tidak lagi hanya tergantung pada sumber daya alam, tetapi sangat dipengaruhi oleh tersedianya sumber daya alam manusia yang tangguh, berpengetahuan luas, kreatif, terampil, dan berkepribadian. Sering terdengar keritikan dan sorotan tentang rendahnya mutu pendidikan oleh masyarakat yang ditujukan oleh lembaga pendidikan, baik secara langsung melalui media elektronik maupun media cetak. Rendahnya mutu pendidikan yang terlihat dari rendahnya hasil belajar diperoleh siswa yang tertera dalam nilai raport.

Namun, kenyataan disekolah masih sering ditemukan sejumlah siswa yang memperoleh prestasi belajar rendah, terutama untuk pelajaran biologi. Rendahnya prestasi dalam bidang biologi sebagai salah satu bagian dari ilmu pengetahuan alam (IPA) khususnya disekolah menjadi masalah yang harus mendapat banyak perhatian dan pemecahan. Dalam hal ini tidak dapat dipungkiri bahwa ada faktor yang mempengaruhi siswa dalam proses pembelajaran. Misalnya faktor internal dan faktor eksternal, banyak faktor yang menyebabkan prestasi belajar rendah, diantara dapat berasal dari dalam diri siswa (faktor internal) maupun dari luar diri siswa (faktor eksternal).

Faktor internal mencakup minat siswa, bakat, dan intelegensi sedangkan faktor eksternal metode belajar, fasilitas belajar, media proses belajar di sekolah maupun diluar sekolah. Studi pendahuluan program 
pengalaman (PPL) yang telah dilakukan oleh peneliti pada salah satu sekolah membuktikan bahwa tingkat pencapaian hasil belajar IPA masih rendah, hal ini dapat dilihat dari nilai rata-rata pada siswa. Dari permasalahan diatas, perlu diterapkan suatu model pembelajaran ipa yang diharapkan dapat meningkatkan minat belajar siswa. Salah satu model pembelajaran yang mampu meningkatkan hasil belajar siswa adalah model pembelajaran Modelling The Way.

Berdasarkan latar belakang di atas, peneliti akan melakukan penelitian yang berjudul "Meningkatkan Hasil Belajar Siswa dengan Menggunakan Model Pembelajaran Modelling The Way Pada Mata Pelajaran IPA Kelas V SD Muhamadiyah Cendana Asri Kec. Batang Kuis T.A. 2016/2017”.

\section{METODE PENELITIAN}

Jenis penelitian ini adalah penelitian tindakan kelas (classrom action research) dengan menggunakan model Modelling The Way sebagai sasaran utama. Dimana penelitian ini berupaya memaparkan penggunaan Model Modelling The Way dalam pembelajaran IPA untuk meningkatkan hasil belajar siswa kelas V dalam pokok bahasan Alat peredaran darah pada manusia di SD Muhammadiyah Cendana Asri Kec. Batang Kuis.

Sesuai dengan jenis penelitian, yaitu penelitian tindakan kelas maka penelitian ini memiliki beberapa tahap pelaksanaan tindakan yakni dua siklus dimana setiap siklus mempunyai empat tahap yaitu: perencanaan, tindakan, observasi, refleksi, dan evaluasi. Berikut akan dijelaskan tahapan per siklus.

Siklus I dilakukan dengan tujuan untuk mencoba penerapan model Modelling The Way pada pembelajaran guna meningkatkan hasil belajar siswa dalam pembelajaran IPA materi pokok peredaran darah ada manusia di kelas V SD Muhammadiyah Cendana Asri Kec. Batang Kuis. Adapun langkahlangkahnya sebagai berikut.

Pada tahap perencanaan, peneliti mengadakan beberapa kali pertemuan dengan guru kelas sebagai mitra kolaborasi untuk membahas teknik pelaksanaan penelitian tindakan kelas. Dalam pertemuan tersebut dikaji kurikulum sebagai acuan untuk materi pelajaran antara lain:

a. Membuat rencana pelaksanaan pembelajaran (RPP) dengan model Modelling The Way.

b. Membuat soal-soal latihan/tugas yang akan diberikan pada masingmasing siswa berdasarkan kompetensi dasar yang dipelajari.

c. Menyusun format atau lembar observasi yang akan digunakan.

d. Menyusun tes untuk mengukur hasil belajar siswa selama tindakan penelitian ditetapkan. 
Kegiatan yang dilaksanakan pada tahap ini adalah melaksanakan pembelajaran sesuai dengan skenario pembelajaran yang telah disusun. Kegiatan yang dilakukan pada tahap ini antara lain:

a Peneliti memberikan penjelasan dan sedikit gambaran tentang materi Peredaran Darah pada Manusia.

b. Peneliti menjelaskan cara menyelesaikan soal latihan pokok bahasan Peredaran Darah pada Manusia. Peneliti memberi kesempatan kepada siswa untuk bertanya, jika ada penjelasan yang kurang dipahami.

c. Peneliti meminta siswa mengerjakan soal latihan yang telah disiapkan oleh peneliti.

d. Membimbing siswa membuat kesimpulan yang diperoleh.
Kegiatan yang dilakukan pada tahap ini adalah melakukan evaluasi terhadap pelaksanaan tindakan dengan menggunakan lembar observasi untuk siswa serta lembar tes untuk mengetahui keberhasilan siswa.

Pada tahap ini dilakukan analisa hasil observasi dan hasil evaluasI untuk mengetahui berhasil atau tidaknya tindakan yang dilakukan. Apabila pelaksanaan siklus I belum tuntas berdasarkan indikator keberhasilan, maka hasil refleksi digunakan sebagai dasar untuk perencanaan siklus berikutnya

\section{HASIL DAN PEMBAHASAN}

Dengan menggunakan model pembelajaran Modelling The Way, maka hsil belajar siswa akan mengalami peningkatan, hal ini dapat dilihat pada tabel 8 di bawah ini:

Tabel 8. Hasil Belajar Siswa

\begin{tabular}{|r|c|c|c|c|}
\hline No. & Siklus & $\begin{array}{r}\text { Jumlah Siswa Yang Hasil } \\
\text { Belajarnya Tuntas }\end{array}$ & Persentase & $\begin{array}{c}\text { Rata-Rata Ketuntasan } \\
\text { Hasil Belajar Siswa }\end{array}$ \\
\hline 1. & Pra siklus & 10 & $31,25 \%$ & 52,5 \\
\hline 2. & Siklus I & 18 & $56,25 \%$ & 66 \\
\hline 3. & Siklus II & 29 & $90,62 \%$ & 81,8 \\
\hline
\end{tabular}

Dari tabel 8 di atas, dapat dilihat bahwa hasil pencapaian hasil belajar sebelum siklus I yaitu: sebanyak 10 siswa atau $(31,25 \%)$ yang tutas dengan nilai rata-rata kelas sebanyak 52,5. Siswa yang tuntas pada siklus I sebanyak 18 siswa atau $(56,25 \%)$ yang tuntas dengan nilai rata-rata 66, sedangkan siswa yang tuntas pada siklus II sebanyak 29 siswa $(90,62 \%)$ dengan nilai rata-rata 81,8 . Dalam hal ini pembelajaran IPA 
dengan menggunakan model manusia dapat meningkatkan hasil pembelajaran Modelling The Way belajar.

materi alat peredaran darah pada

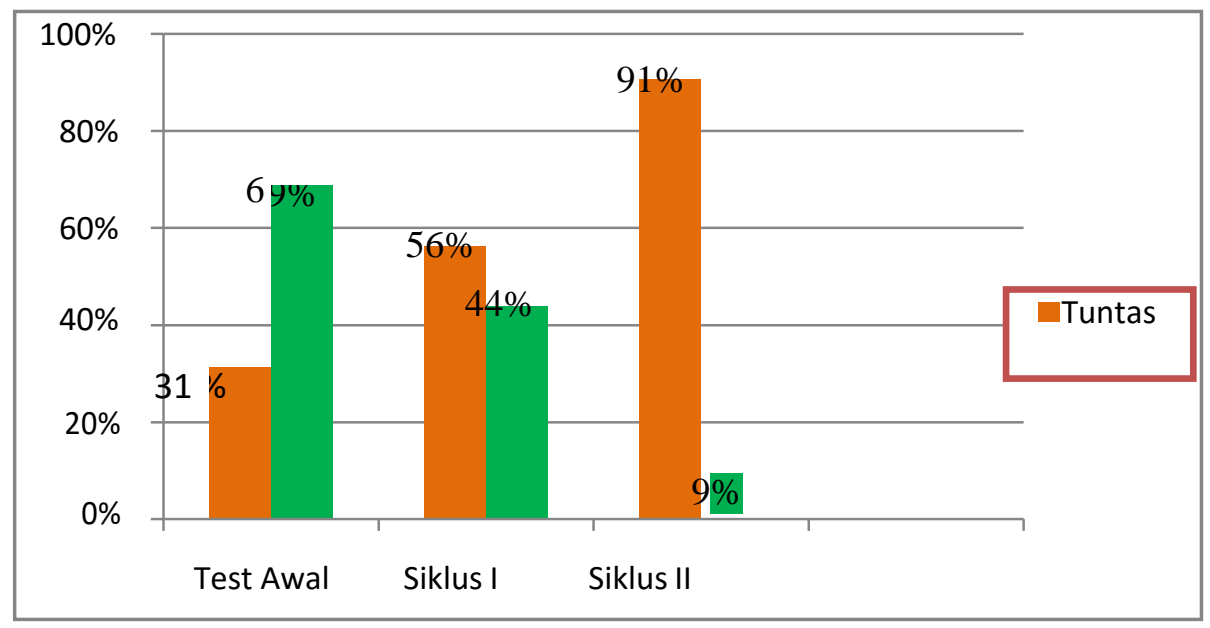

Gambar 4.3.2 Diagram Persentase Peningkatan Hasil Belajar

Tertanyata setelah melakukan tindakan dengan menggunakan model pembelajaran Modelling The Way di kelas V SD Muhammadiyah Cendana Asri, hasil belajar siswa meningkat, sebab siswa termotivasi untuk belajar karena siswa terlibat aktif dalam prose pembelajaran dan pemahaman siswa akan pembelajaran IPA semakin luas.

\section{Dengan}

penggunaan model pembelajaran Modelling The Way dapat meningkatkan hasil belajar. Berdasarkan tabel 8 dan diagram di atas dapat diketahui bahwa hasil belajar siswa pada siklus I pertemuan I menunjukkan hasil belajar siswa pada pelajaran IPA.

\section{SIMPULAN}

Berdasarkan analisis data yang dilakukan peneliti maka dapat ditarik beberapa kesimpulan yaitu:

1. Dengan menggunakan model pembelajaran Modelling The Way dapat mempermudah siswa dalam memahami pembelajaran IPAs khususnya pada materi pokok alat peredaran darah manusia.

2. Penggunaan model pembelajaran Modelling The Way dapat meningkatkan hasil belajar siswa pada mata pelajaran IPA masih sangat rendah yaitu sebanyak 22 orang siswa dinyatakan belum tuntas hasil belajarnya $(68,75 \%)$ dan hanya 10 orang siswa dinyatakan tuntas $(32,25 \%)$ yang tergolong cukup hasil belajarnya. Peningkatan hasil belajar siswa pada pelajaran IPA materi alat peredaran darah pada manusia . pada 
pre test yaitu 52,5 atau $31,25 \%$, pada siklus I terjadi peningkatan menjadi 66 atau sebesar 56,25\% dan pada siklus II peningkatan semakin terlihat menjadi 81,8 atau $90,62 \%$.

3. Pada soal pre test yang dilakukan peneliti, nilai rata-rata yang diperoleh siswa adalah 52,5 dengan persentase ketuntasan $31,25 \%$ atau jumlah siswa yang tuntas sebanyak 10 siswa. Jumlah siswa yang tidak tuntas sebanyak 22 siswa atau $68,75 \%$.

4. Dari pelaksanaan siklus I, nilai rata-rata yang diperoleh siswa adalah 66 dengan persentase ketuntasan 56,25\% atau jumlah siswa yang tuntas sebanyak 18 siswa. Jumlah siswa yang tidak tuntas sebanyak 14 siswa atau $43,75 \%$.

5. Hasil pelaksanaan siklus II dapat dilihat bahwa nilai rata-rata siswa meningkat yaitu 81,5 dengan persentase ketuntasan $90,62 \%$ atau siswa yang tuntas sebanyak 29 siswa. jumlah siswa yang tidak tuntas sebanyak 3 siswa atau $9,37 \%$.

Dari kesimpulan di atas, maka peneliti memberikan saran sebagai berikut :

1. Kepada guru dihimbau untuk melakukan proses pembelajaran dengan menggunakan model pembelajara Modelling The Way pada mata pelajaran IPA agar siswa lebih bersemangat dalam belajar.

2. Kepada kepala sekolah hendaknya membuat program kepada guru tentang model pembelajaran yang akan diterapkan sehingga proses pembelajaran dapat berkembang.

3. Dengan menggunakan model pembelajaran Modelling The Way siswa diharapkan lebih bersemangat dan bisa berinteraksi satu sama lain serta mampu bekerjasama dalam kelompok.

4. Kepada peneliti selanjutnya yang ingin menggunakan jenis penelitian yang sama sebaiknya dilaksanakan dengan menggunakan waktu yang lama agar mendapatkan hasil yang lebih baik lagi.

\section{DAFTAR RUJUKAN}

Abdullah. 2011. Ilmu Pengetahuan Alam (IPA). Jakarta: Bumi Aksara.

Arikunto. 2006. Penelitian Tindakan Kelas. Jakarta: Rineka Cipta.

Depdiknas. 2007. Kamus Besar Bahasa Indonesia. Jakarta: Balai Pustaka.

Hamid. 2011. Model Pembelajaran. Jakarta: Bumi Aksara.

Hamalik, Oemar. 2001. Kurikulum dan Pembelajaran. Jakarta: Bumi Aksara. 
Hamalik, Oemar. 2001. Proses Belajar Mengajar. Bandung: Bumi Aksara.

Istarani. 2011. Model Modelling The Way. Medan: Media Persada.

Jurnal,untan.ac.id/index.php/jpdpb/art icle/view/2169/2110. Diakses hari Minggu tanggal 14 Februari 2016 pukul 15.53.

Joyce, Bruce \& Marsha Weil. 1980. Models of teaching, fifth Edition.USA: Allyn and Bacon A Simon \& Scuster Company.

Mardianto. 2009. Psikologi Pendidikan. Bandung: Cita Pustaka Media Perintis.

Nasution,

Anwar. 2006.

Pembelajaran Aktif di Sekolah Dasar. Jakarta: Dynasti.

Purwanto. 2011. Evaluasi Hasil Belajar. Yogyakarta: Pustaka Pelajar.

Bundu, Patta. 2006. Pembelajaran Ilmu Pengetahuan Alam. Bandung: CV. Andi.

Rasyid, Harun dan Mansur. 2009.

$\begin{array}{ccc}\text { Penilaian Hasil Belajar. } & \text { Bandung: } \\ \text { CV. } & \text { Wacana }\end{array}$
Prima.

Santoso. 2011. Model Pembelajaran. Jakarta : Bumi Aksara.
Slameto. 2010. Belajar Dan FaktorFaktor yang Mempengaruhinya. Jakarta: Rineka Cipta.

Sudjana. 2011. Belajar dan Pembelajaran. Jakarta: PT. Grafindo.

Sudjana. N, 2009. Penilaian Hasil Proses Belajar Mengajar. Bandung: PT. Remaja Rosdakarya.

Sugiyono. 2008. Metodologi Penelitian Pendidikan. Bandung: Alfabeta.

Supridjono. 2009. Model Pembelajaran. Bandung: Vidia Pustaka.

Suyadi. 2011. Ilmu Pengetahuan Alam Kelas V. Jakarta: Balai Pustaka.

Trianto. 2010. Mendesain Model Pembelajaran InovatifProgresif. Jakarta : Kencana Prenada Media Group.

Usman, Moh. Uzer. 2009. Menjadi Guru Profesioal. Bandung: PT. Remaja Rosdakarya. 